\title{
PSYCHE
}

\begin{tabular}{lll}
\hline Vol. 94 & 1987 & No. 1-2 \\
\hline
\end{tabular}

\section{THE FOSSIL MEMBERS OF THE ANT TRIBE LEPTOMYRMECINI (HYMENOPTERA: FORMICIDAE)}

\section{By Cesare Baroni Urbani ${ }^{1}$ and Edward O. Wilson ${ }^{2}$}

In 1980 Baroni Urbani described Leptomyrmex neotropicus from 9 rather poorly preserved specimens clustered in a single piece of Dominican amber and hence presumed to be of Miocene age (the date estimated in Baroni Urbani and Saunders, 1982). The finding is of potential biogeographic importance because Leptomyrmex, and hence the very distinctive dolichoderine tribe Leptomyrmecini, is today limited to the Old World, in particular eastern Australia, New Caledonia, New Guinea, the Aru Islands, and the Moluccas. A second genus, Leptomyrmula, had previously been described from the Miocene amber of Sicily (Emery, 1891, 1912). It thus appears that an entire tribe was once almost worldwide but has since retreated not only from Europe but the entire Western Hemisphere. Wilson (1985a) doubted Baroni Urbani's tribal placement of the Dominican amber specimens. He found a worker in Dominican amber that superficially resembles Leptomyrmex, sharing the same distinctively elongated body form, mesothoracic constriction, petiole, tapered neck, and bulging eyes located toward the rear of the head, but actually belongs to the Camponotus branneri group. He suggested that Leptomyrmex neotropicus might be the same species. In the meantime, Schlee (1984) published a color photograph of another Dominican amber piece containing four presumed Leptomyrmex workers. This example is now preserved in the collection of

'Zoologisches Institut der Universität Basel, Rheinsprung 9, CH-4051 Basel, Switzerland.

${ }^{2}$ Museum of Comparative Zoology, Harvard University, Cambridge, Massachusetts 02138, USA.

Manuscript received by the editor February 17, 1987. 
the Museum für Naturkunde, Stuttgart, with the reference number Do-4931-M. He has also provided us with four more workers, in a piece labeled Do-4484-M.

Baroni Urbani was right. The additional, better preserved workers are identical or close to L. neotropicus, and prove to belong to the Leptomyrmecini beyond any reasonable doubt. In addition to being so close in overall habitus to the living species of Leptomyrmex as to fall easily within the limits of this genus, the material shows the following distinctive traits in common with that Old World genus:

(1) Slit-shaped anal orifice.

(2) Masticatory border of mandibles smoothly rounded at the basal angle and lined with more than 15 denticles of uniform size, as opposed to fewer than 10 teeth, usually 5-6, decreasing in size from apex to base in species of Camponotus.

(3) Anteriormost point of antennal socket very close to the posterior clypeal border (in Camponotus the two are widely separated).

(4) Large metapleural gland orifice and prominent bulla (in Camponotus bulla small and orifice absent).

(5) Metathoracic spiracles on dorsum of alitrunk (usually lateral in Camponotus).

In addition, Wilson has acquired a male that appears to be a leptomyrmecine, although it possesses at least one trait (absence of the radial cell) that might eventually justify separating it at the generic level from both Leptomyrmex and Leptomyrmula.

\section{Status of Leptomyrmex neotropicus Reexamined}

The main features of a well-preserved Leptomyrmex are depicted in Figure 1. As noted by Baroni Urbani (1980) for the L. neotropicus types and confirmed with the new worker specimens, the habitus of the fossil species is closest to L. fragilis (= L. gracillimus) of New Guinea, Ceram, and Aru among the living species. This assessment is based on the revision of Leptomyrmex by Wheeler (1934) and the examination of large new collections of that genus placed in the Museum of Comparative Zoology during the ensuing fifty years. $L$. neotropicus differs from fragilis in its smaller size, even narrower head, projection of the compound eyes beyond the lateral borders of the head, and more concave masticatory borders. In a genus with a relative scarcity of worker characters, the small size is especially notable. The specimen shown in Figure 1 possesses the following 


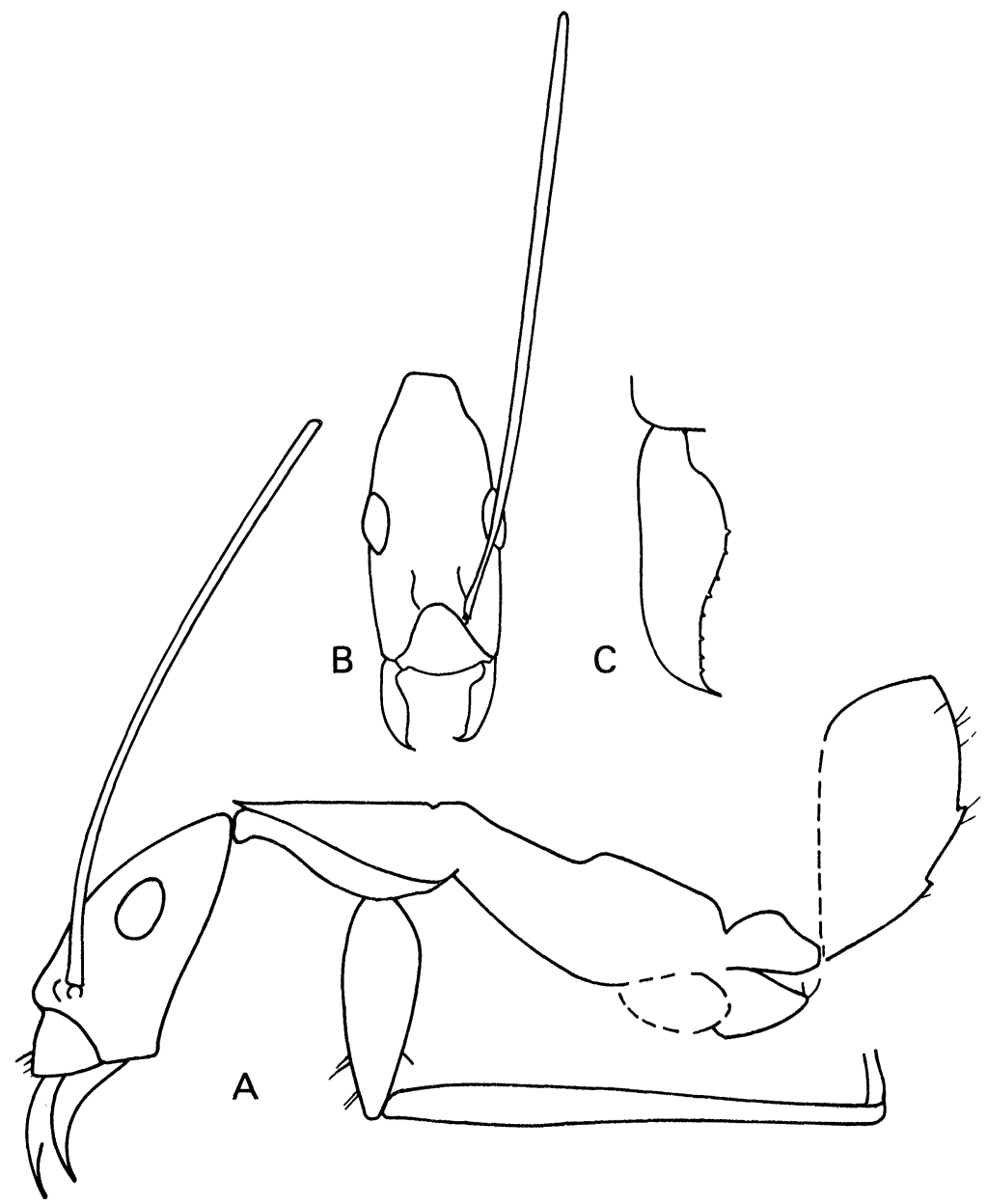

Figure 1. Leptomyrmex neotropicus worker from Miocene amber of the Dominican Republic: A, side view of entire body; B, frontal view of head; C, enlarged view of right mandible tilted anteriorly to give a full frontal aspect.

measurements: Head Length (excluding mandibles) $1.50 \mathrm{~mm}$, Head Width (across and including eyes) $0.72 \mathrm{~mm}$, Scape Length $2.48 \mathrm{~mm}$, Eye Length (longest axis) $0.31 \mathrm{~mm}$, total length (including mandibles) $5.6 \mathrm{~mm}$. A second specimen is smaller: Head Length $1.30 \mathrm{~mm}$, total length $4.6 \mathrm{~mm}$. The four Stuttgart specimens embedded in a single amber piece (Museum reference number Do-4931-M) yielded the following measurements: Head Length $0.80-0.83 \mathrm{~mm}$ (4 speci- 
mens measured), Head Width $0.52 \mathrm{~mm}$ (one specimen measured), Scape Length 1.56-1.66 mm (5 scapes in 3 specimens measured), Eye Length $0.14-0.16 \mathrm{~mm}$ ( 3 eyes on 3 specimens measured), Total Length 4.8-5.5 $\mathrm{mm}$ (4 specimens measured). Three of those in piece number Do-4484-M possessed the following measurements: Head Length $1.20-1.36 \mathrm{~mm}$, Head Width $0.72-0.84 \mathrm{~mm}$, Scape Length 2.40-2.48 mm, Eye Length $0.24-0.26 \mathrm{~mm}$. These dimensions are at the extreme lower end of the variation showed by the extant Leptomyrmex, represented by L. mjobergi of Queensland. Among other important character states of $L$. neotropicus with reference to the extant Leptomyrmex are the lack of hairs on the compound eyes, the almost completely hairless body surface, the narrowly constricted occiput, and the apparently light, uniform body color.

The male that we have tentatively associated with Leptomyrmex neotropicus is illustrated in Figure 2. This specimen is similar to Leptomyrmex and Leptomyrmula in several important respects and is appropriately placed in the tribe Leptomyrmecini, whether it is really the male of $L$. neotropicus or not. The leptomyrmecine traits are as follows: exceptionally slender body form and overall habitus similar to Leptomyrmex and Leptomyrmula; antennae very long; venation reduced and the stigma vestigial or absent. The genitalia unfortunately cannot be studied.

There are also some important differences. First, consider the venation (see Figure 3). Where extant Leptomyrmex species have a peculiarly narrow radial cell, Leptomyrmula maravignae has a wider and hence more "ordinary" radial cell, and L. neotropicus has no radial cell at all. Living Leptomyrmex, with the exception of $L$. fragilis, possess a stigmal appendage ("pterostigmal appendage" of Wheeler, 1934), a unique bladder-like structure extending from the position of the vestigial stigma out into the radial cell. This structure is absent in Leptomyrmula maravignae and the putative Leptomyrmex neotropicus. In the extant Leptomyrmex, the antennae are about $0.7-0.9 \times$ as long as the body; in Leptomyrmula maravignae they are about $0.5 \times$ as long; and in Leptomyrmex neotropicus they are about equally long.

The absence of the stigmal appendage and an exceptionally slender body form are shared by the male of Leptomyrmex neotropicus with the male of the living $L$. fragilis, but there the resemblance ends. $L$. neotropicus is much smaller than $L$. fragilis, has a 


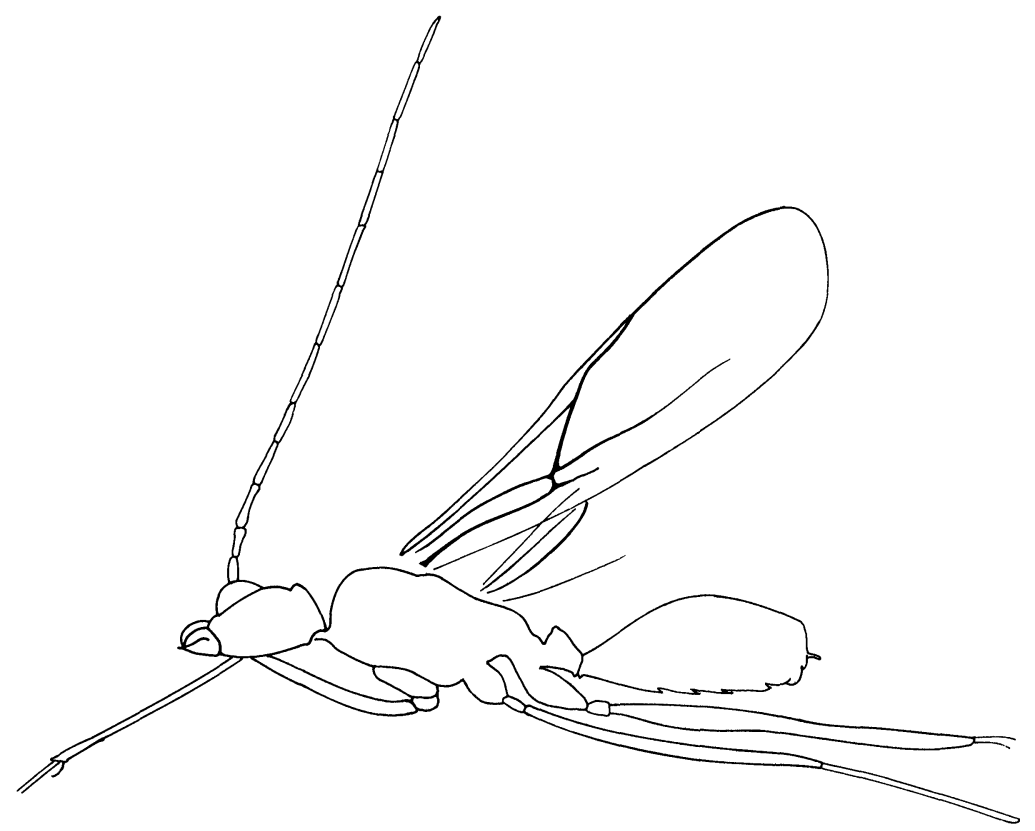

Figure 2. Leptomyrmecine male from the Dominican amber tentatively associated with Leptomyrmex neotropicus.

convex (as opposed to concave) prothorax, lacks the radial cell, and has more fully developed, denticulate mandibles. The mandibular form of $L$. neotropicus is shared with $L$. erythrocephalus and $L$. nigriventris among living species. $L$. fragilis has thinner, strap-like, toothless mandibles; this trait is shared by cnemidatus, darlingtoni, mjobergi, pallens, tibialis, varians, and wiburdi among the extant Leptomyrmex.

\section{Discussion}

The leptomyrmecine male, whether Leptomyrmex neotropicus or not, may be sufficiently different from the living Leptomyrmex and Sicilian amber Leptomyrmula to warrant separation as a distinct genus. However, we do not believe it prudent to take this step until enough material has accumulated to make the worker-male association more probable, and to better estimate the extent of variation in both castes. 


\section{Leptomyrmex tibialis}

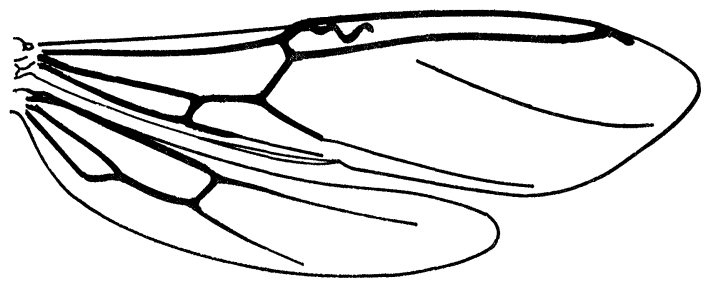

\section{Leptomyrmex neotropicus}

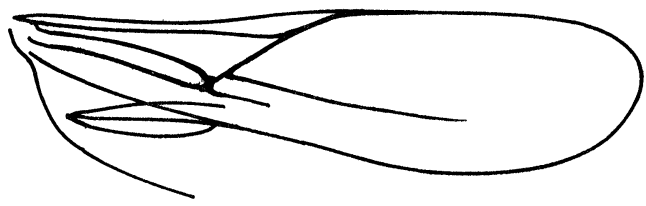

\section{Leptomyrmula maravignae}

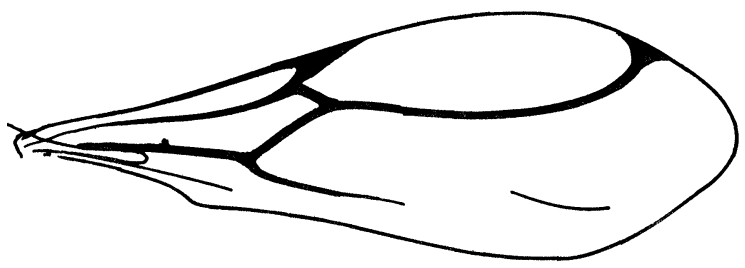

Figure 3. Wings of males of the living Leptomyrmex tibialis of Australia (Wheeler, 1934), Leptomyrmula maravignae of the Sicilian amber (Emery, 1891), and the putative Leptomyrmex neotropicus. 
The picture remains puzzling. If Leptomyrmex neotropicus is really cognate with the living Indo-Australian Leptomyrmex, that is, derived from an immediately common ancestor, then the Leptomyrmecini have undergone a dramatic retreat since later Tertiary times. The only other ant group with a comparable history is the Aneuretinae, which once ranged through Europe (Baltic amber, Oligocene; see Wheeler, 1914) and North America (Florissant shales, Oligocene; see Carpenter, 1930), but now is known only from Aneuretus simoni of Sri Lanka in the living world fauna (Jayasuriya and Traniello, 1985). The peculiarity of the leptomyrmecine case is heightened by the distinctively modern character of the Dominican amber fauna in which it occurs: of $\mathbf{3 7}$ genera and well-defined subgenera of ants recorded to date, 34 have survived somewhere in the New World tropics; only three are absent, and these are extinct everywhere in the world (Wilson, 1985b).

It is of course possible that Leptomyrmex neotropicus represents a wholly convergent line to the Old World "true" Leptomyrmecini, but we consider that unlikely. The character states possessed in common seem too numerous and detailed to be convergent. However, the matter will be settled wih confidence only with the acquisition and study of larger series.

\section{SUMMARY}

Additional specimens have confirmed the existence of the ant tribe Leptomyrmecini in Miocene amber of the Dominican Republic. The workers of the species, Leptomyrmex neotropicus, are not distinguishable at the generic level from the living Leptomyrmex of Australia and Melanesia, but the male tentatively associated with the workers has peculiarities in wing venation that may eventually justify a separation from Leptomyrmex as well as from Leptomyrmula of the Miocene Sicilian amber. This is the only higher ant taxon other than the subfamily Aneuretinae known to have gone extinct in the New World while surviving in the Old World.

\section{ACKNOWLEDGMENTS}

We are grateful to Major Jake Brodzinsky of Amberica, Inc., George Poinar of the University of California, Berkeley, and Dieter Schlee of the Museum für Naturkunde, Stuttgart, for supplying the material used in this study. 


\section{ReferenCes Cited}

Baroni URBani, C.

1980. The first fossil species of the Australian ant genus Leptomyrmex in amber from the Dominican Republic. Stuttgarter Beiträge zur Naturkunde, Serie B, 62: 1-10.

Baroni Urbani, C. and SaUnders, J. B.

1982. The fauna of the Dominican Republic amber: the present status of knowledge. Transactions of the Ninth Caribbean Geological Conference, Santo Domingo, 1980(1982), 1: 213-223.

CARPEnter, F. M.

1930. The fossil ants of North America. Bulletin of the Museum of Comparative Zoology, Harvard, 70(1): 1-66, 11 plates.

EMERY, C.

1891. Le formiche dell'ambra Siciliana nel Museo Mineralogico dell'Universita di Bologna. Memorie della Reale Accademia delle Scienze dell'Instituto di Bologna, (5)1: 1-26.

1912. Hymenoptera. Fam. Formicidae. Subfam. Dolichoderinae. Genera Insectorum, 137: 1-50, 2 plates.

Jayasuriya, Anula K. and Traniello, J. F. A.

1985. The biology of the primitive ant Aneuretus simoni (Emery) (Formicidae: Aneuretinae). I. Distribution, abundance, colony structure, and foraging ecology. Insectes Sociaux, 32(4): 363-374.

SCHLEE, D. (ED.)

1984. Bernstein-Neuigkeiten. Stuttgarter Beiträge zur Naturkunde, Serie C 18: $1-100$.

WHEELER, W. M.

1914. The ants of the Baltic amber. Schriften der Physikalisch-Ökonomischen Gesellschaft zu Königsberg, 55: 1-142.

1934. A second revision of the ants of the genus Leptomyrmex Mayr. Bulletin of the Museum of Comparative Zoology, Harvard, 77(3): 69-118.

WILSON, E. O.

1985a. Ants of the Dominican amber (Hymenoptera: Formicidae). 3. The subfamily Dolichoderinae. Psyche, 92(1): 17-37.

1985b. Invasion and extinction in the West Indian ant fauna: evidence from the Dominican amber. Science, 229: 265-267. 

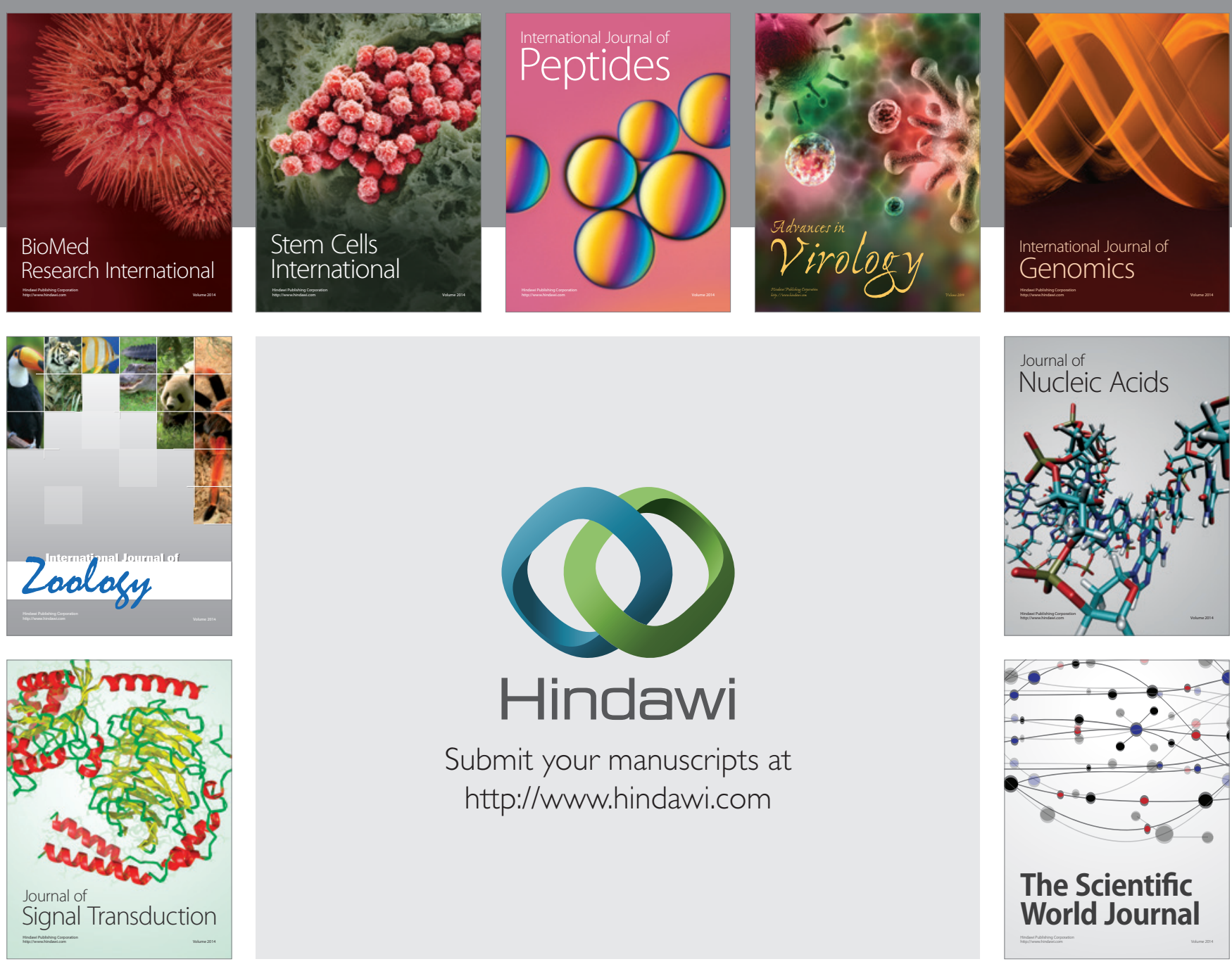

Submit your manuscripts at

http://www.hindawi.com
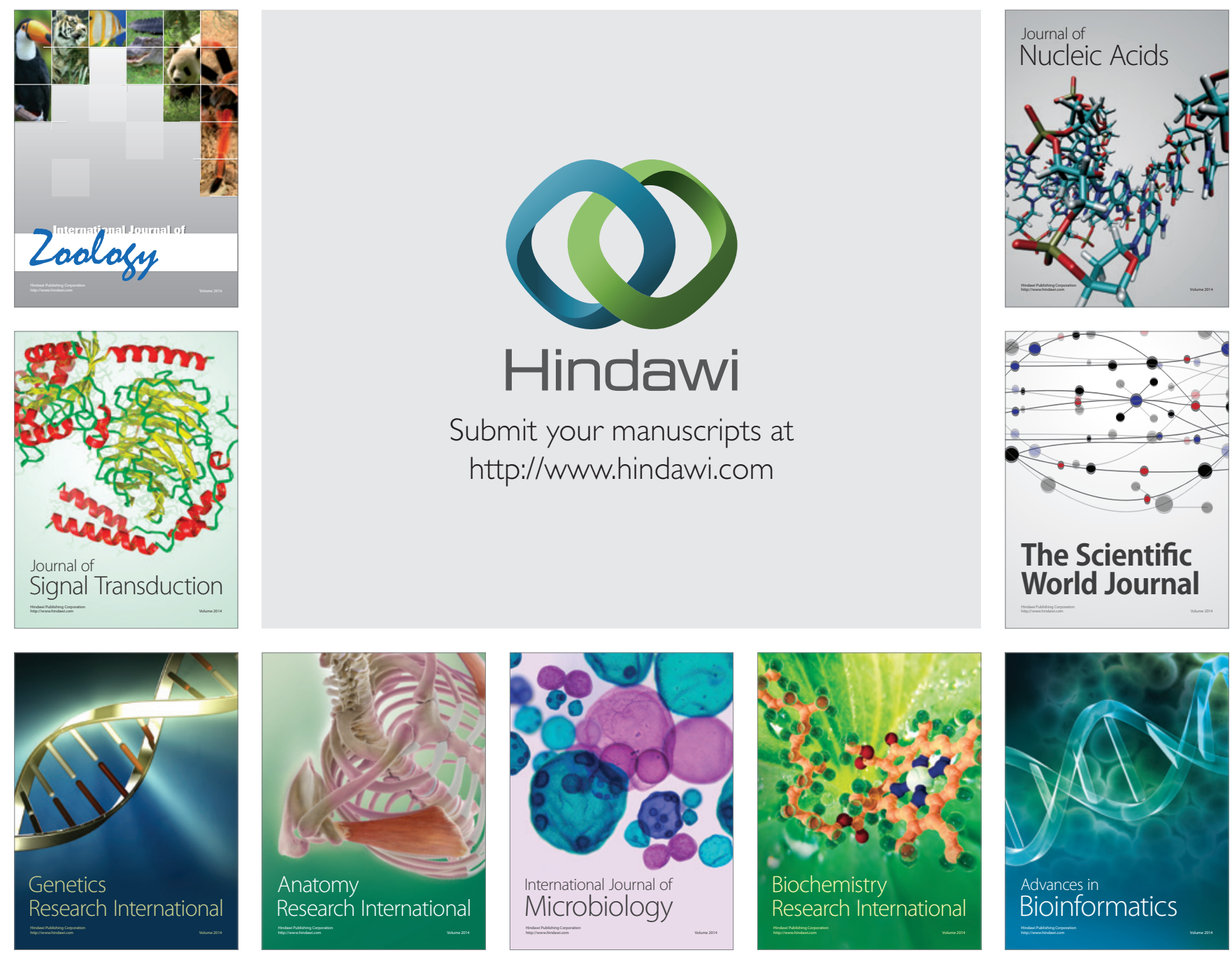

The Scientific World Journal
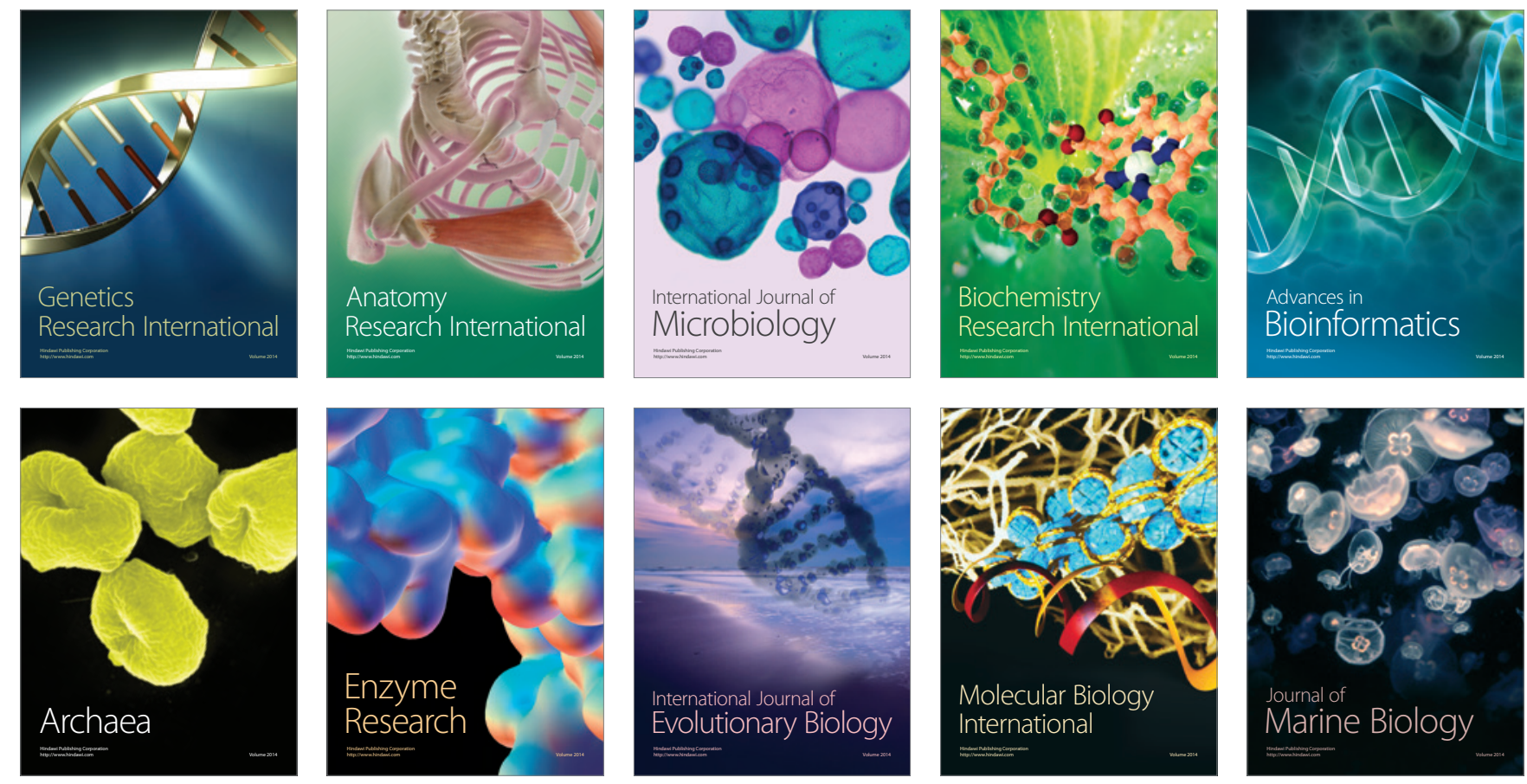